av behandlingen, ettersom totalrisiko er aldersavhengig, og den høye alderen slår ut nesten alt annet. Et sterkt søkelys på en moderat blodtrykksforhøyelse kan utløse mye engstelse hos et gammelt menneske som for øvrig opplever mye sykdom og død rundt seg (4).

Jeg kan ikke se at tiden er moden for en generell anbefaling om screening og forebyggende behandling av friske 80-90-åringer, men klinisk forskning for å klarlegge nytte, risiko og bivirkninger av blodtrykksbehandling i denne aldersgruppen må ønskes velkommen. I denne aldersgruppen må vi først og fremst behandle sykdom og symptomer, seponere uheldige medikamentkombinasjoner og utvise forsiktighet ved medikamentelle forebyggende intervensjoner.

\section{Bjørn Gjelsvik}

bjorn.gjelsvik@medisin.uio.no

Bjørn Gjelsvik (f. 1949) er fastlege og forsker ved Avdeling for allmennmedisin, Institutt for helse og samfunn, Universitetet i Oslo.

Oppgitte interessekonflikter: Han har vært medlem av faggruppen som utarbeidet de nasjonale faglige retningslinjene for primærforebygging av hjerte-og karsykdom.

\section{Litteratur}

1. Law MR, Morris JK, Wald NJ. Use of blood pressure lowering drugs in the prevention of cardiovascular disease: meta-analysis of 147 randomised trials in the context of expectations from prospective epidemiological studies. BMJ 2009; 338: b1665.

2. Wright JM, Musini VM. First-line drugs for hypertension. Cochrane Database Syst Rev 2009; nr. 3: CD001841.

3. Beckett NS, Peters R, Fletcher AE et al. Treatment of hypertension in patients 80 years of age or older. N Engl J Med 2008; 358: 1887-98.

4. Lipsitz LA. A 91-year-old woman with difficult-to-control hypertension: a clinical review. JAMA 2013; 310: 1274-80.

Dette er en redigert versjon av debatten, publisert som rask respons på nett 14.10.2013. http://tidsskriftet.no/article/3058042/

\section{Endring innenfor analytisk variasjon}

I Tidsskriftet nr. 17/2013 fremfører Rune Ulvik et statistisk resonnement (1), mens mitt poeng var at det måtte tas hensyn til biologisk og analytisk variasjon $i$ tolkningen av prøvene.

I studien (2) dokumenterte Ulvik og medarbeidere at medianverdien for hemoglobin økte med $0,4 \mathrm{~g} / 100 \mathrm{ml}$ i både høydosegruppen og lavdosegruppen. Analytisk variasjon på $1 \%$ med $95 \%$ konfidensintervall for en medianverdi for hemoglobin på $12,5 \mathrm{~g} / 100 \mathrm{ml}$ vil tilsi en akseptabel analytisk variasjon innenfor $0,74 \mathrm{~g} / 100 \mathrm{ml}$. En endring av hemoglobinnivået på 0,4 eller $0,5 \mathrm{~g} / 100 \mathrm{ml}$ dokumenterer etter mitt skjønn altså ikke at hemoglobinnivået har økt som følge av intervensjonen.

\section{Krystyna Sandvik}

krystyna.sandvik@ous-hf.no

Krystyna Sandvik (f. 1959) er bioingeniør ved Avdeling for medisinsk biokjemi, Universitetssykehuset i Oslo, Rikshospitalet.

Ingen oppgitte interessekonflikter.

\footnotetext{
Litteratur

1. Ulvik RJ, Møller R, Hervig T. Kosttilskudd med jern ved jernmangel. Tidsskr Nor Legeforen 2013; 133: 845-9.
}

2. Bjørndal A, Hofoss D. Statistikk for helse og sosialfagene. Oslo: Gyldendal, 2010.

Dette er en redigert versjon av debatten, publisert som rask respons på nett 7.10. 2013. http://tidsskriftet.no/article/3058455/

\section{R.J. Ulvik svarer:}

I vår artikkel målte vi hemoglobinnivå før og etter tilskudd med lavdose- og høydosejern (1). Differansen mellom parvise data i de to målesettene var normalfordelt. Tilfeldig variasjon forårsaket av intraindviduell biologisk variasjon og analytisk variasjon, forutsettes å være den samme ved gjentatt prøve ved to ulike tidspunkter hos samme individ (2).

I artikkelen brukte vi Wilcoxon signed-rank test som tester om medianen i fordelingen av differansene er lik eller forskjellig fra null (3). Tilsvarende parametrisk test er paret t-test for gjennomsnittet i fordelingen. Disse testene danner grunnlaget for beregning av p-verdi og for vurdering av om behandlingen gir en statistisk signifikant forskjell $i$ hemoglobinverdi ved de to måletidspunktene.

Bruk av paret t-test (ikke beskrevet i artikkelen) ga lavere p-verdi enn bruk av Wilcoxon signed-rank test: for lavdosejern 0,0002 versus 0,0004 , og for høydosejern 0,003 versus 0,005 . Vi har brukt anerkjente statistiske metoder for å vurdere forskjell mellom parvise data i to målesett. Det kan virke som om Sandvik mener dette er feil uten at hun har utdypet det nærmere. Jeg takker for en interessant diskusjon som herved avsluttes fra min side.

\section{Rune J. Ulvik}

rune.ulvik@k2.uib.no

Rune J. Ulvik (f. 1947) er professor og overlege ved Klinisk institutt 2 og Laboratorium for klinisk biokjemi, Universitetet i Bergen Oppgitte interessekonflikter: Han har mottatt reisetilskudd fra Cederroth AS.

Litteratur

1. Ulvik RJ, Møller R, Hervig T. Kosttilskudd med jern ved jernmangel. Tidsskr Nor Legeforen 2013; 133: 845-9.

2. Altman DG. Practical statistics for medical research. London /New York: Chapman \& Hall/CRC, 1991: 187-90.

3. Peat J, Barton B. Medical statistics. A guide to data analysis and critical appraisal. Oxford: Blackwell, 2005: 92.

Dette er en redigert versjon av debatten, publisert som rask respons på nett 14.10.2013. http://tidsskriftet.no/article/3058455/

\section{Interessant om elsykkel}

I Tidsskriftet nr. 17/2013 (1) vises det til en studie hvor man har funnet at bruk av elsykkel gir tilstrekkelig treningseffekt (2). Denne informasjonen er viktig å få frem. Mange, med meg, kvier seg for de lange, bratte bakkene. Dette kan senke terskelen. Er det noen som vet hva man kan velge av løsninger og modeller?

\section{Tore Gutteberg}

tore.gutteberg@unn.no

Tore Gutteberg (f. 1945) er overlege og professor ved Avdeling for mikrobiologi og smittevern, Universitetssykehuset Nord-Norge.

Ingen oppgitte interessekonflikter.

Litteratur

1. Lobben SE. Elsykkel til jobb gir treningseffekt. Tidsskr Nor Legeforen 2013; 132 1812.

2. Gojanovic B, Welker J, Iglesias $K$ et al. Electric bicycles as a new active transportation modality to promote health. Med Sci Sports Exerc 2011; 43: 2204-10.

Dette er en redigert versjon av debatten, publisert som rask respons på nett 24.9.2013. http://tidsskriftet.no/article/3059062/ 